\title{
COMMENTARY
}

\section{Achieving the Sustainable Development Goals in Africa: Call for a Paradigm Shift}

\section{Kole Shettima}

The MacArthur Foundation

*For Correspondence: Email: kshettim@ macfound.org

Heads of States and Governments met in New York at the General Assembly in September 2015 to agree to a set of successor goals to the Millennium Development Goals (MDGs) known as Sustainable Development Goals (SDGs). Tagged "Leave No One Behind", the SDGs is different in many respects from the MDGs. It is more ambitious (17 goals and 169 targets), developed through better consultative, transparent and participatory process, and commits all countries of the world. In comparison, the MDG had limited goals and targets (8 goals and 18 targets), less consultative, transparent and participatory, and are only applicable to developing countries ${ }^{1}$.

The 17 Goals of the SDGs include: the eradication of poverty, end hunger, good health and well-being, quality education, gender equality, clean water and sanitation, affordable and clean energy, decent work and economic growth, industry, innovation and infrastructure, reduced inequalities, sustainable cities and communities, responsible consumption and production, climate action, life below water, life on land, peace, justice and strong institutions and partnerships for the goals ${ }^{2}$. These ambitious and all-encompassing goals are to be met by the year 2030 .

Africa played significant roles in the process of development of the SDGs ${ }^{3}$. The High Level Panel on the post-2015 development agenda was co-chaired by Ellen Johnson Sirleaf, President of Liberia, and 5 other Africans were members. Furthermore, the UN President of the General Assembly and the co-facilitator of the intergovernmental negotiations and the Chair of the G77+China were from the region. Nigeria's Amina Mohammed was the lead facilitator for the development of the SDGs. Addis Ababa hosted the Third International Conference on Financing for Development (FFD3) in July 2015 which set to guide development financing for years to come. Fortunately, the SDGs dovetails with Africa's priorities as articulated in the Common African Position, "Agenda 2063, the Africa we want"4. The 7 aspirations in the Agenda 2063 capture most elements of the SDGs: a prosperous Africa based on inclusive growth and sustainable development; an integrated continent, politically united based on the ideals of Pan Africanism and the vision of Africa's Renaissance; an Africa of good governance, democracy, respect for human rights, justice and the rule of law; a peaceful and secure Africa; an Africa with a strong cultural identity, common heritage, values and ethics; an Africa, whose development is people-driven, relying on the potential of African people, especially its women and youth, and caring for children; and Africa as a strong, united, resilient and influential global player and partner. This commonality of ideas helps to integrate the two aspirations and limit competitive ideas.

It is widely recognized that the SDGs will only succeed, however, if they succeed in Africa. A projection of how Africa will fare in terms of reaching the goals in 2030 paints a bleak picture. The analysis suggests three categories: those that require reform, those that require revolution and those that require reversal. The first category assumes that it would take these targets more than half way to achievement by 2030 and these are economic growth (Goal 8) and strengthening domestic resource mobilization for development (Goal 17). The second category is those targets where progress needs to speed up by multiples of current rates to meet the target. These include ending extreme poverty (Goal 1), eliminating hunger (Goal 2), reducing maternal mortality (Goal 3), quality education (Goal 4), gender equality (Goal 5), access to sanitation (Goal 6), access to energy (Goal 7), industrialization in 
LDCs (Goal 9), reducing inequality (Goal 10) and halting deforestation (Goal 15). The third category is where the targets are heading in the wrong direction. They include reducing slum populations (Goal 11), reducing waste (Goal 12), combating climate change (Goal 13), marine conservation (Goal 14) and reducing violent deaths (Goal 16) .

The goals are interconnected as the effect of one goal has tremendous effect on the others. However, I believe that achieving gender equality (Goal 5) will revolutionize the achievement of the other goals and is sin qua non for the achievement of the other goals and for the general attainment of the values and ideas of SDGs. The targets for Goal 5 are:

1. End all forms of discrimination against all women and girls everywhere.

2. Eliminate all forms of violence against all women and girls in the public and private spheres, including trafficking and sexual and other types of exploitation.

3. Eliminate all harmful practices, such as child, early and forced marriage and female genital mutilation.

4. Recognize and value unpaid care and domestic work through the provision of public services, infrastructure and social protection policies and the promotion of shared responsibility within the household and the family as nationally appropriate.

5. Ensure women's full and effective participation and equal opportunities for leadership at all levels of decision making in political, economic and public life.

6. Ensure universal access to sexual and reproductive health and reproductive rights as agreed in accordance with the Program of Action of the International Conference on Population and Development and the Beijing Platform for Action and the outcome documents of their review conferences.

7. Undertake reforms to give women equal rights to economic resources, as well as access to ownership and control over land and other forms of property, financial services, inheritance and natural resources, in accordance with national laws.

8. Enhance the use of enabling technology, in particular information and communications technology, to promote the empowerment of women.

9. Adopt and strengthen sound policies and enforceable legislation for the promotion of gender equality and the empowerment of all women and girls at all levels ${ }^{6}$.

Significant progress was achieved towards gender equality and women's empowerment under the Millennium Development Goals including the target of access to primary education between girls and boys. However, gender equality is still out of sight. Many of the targets under Goal 5 of the SDGs are embedded in cultural and social norms and values which make them harder to change. Legislation and policies can be invoked to reach some of the targets and they may be necessary first steps. Whereas there is no silver bullet for gender equality, girls' education is one weapon that can make a significant difference because of the potential of changing norms and values. I recall a conversation with a governor who made the point better. I was disturbed about the rate of divorce, the high number of divorced women and the ease at which women could be divorced in his state. I suggested legislation to curtail the situation including minimum age at marriage and stricter conditions for divorce. He appreciated my concern and solution but reminded me that as a politician the suggestion will not only be difficult to implement but may not be effective and raise controversies that could consume the administration. He made the point that religious, political and traditional leaders will seize on any move to legislate and create chaos. They would be fighting him until the next election. His political career will be truncated because of demonization. The solution, according to him, is to ensure that every girl attend a minimum of secondary education. Each should enjoy free education including free transportation, uniforms and meals. He thinks that by the time a girl reaches the age of $17 / 18$, she can make many decisions that will respond to the targets of Goal 5.

I believe free and compulsory education is necessary for the attainment of the many targets of Goal 5. In addition, we must pay attention to the quality and functionality of the education. There is 
no point in producing illiterate adolescents and adults and those without any skills. It means we must implement faithfully two documents adopted by the Government. These are the new senior secondary school curriculum which incorporates technical and vocational skills and the national sexuality education curriculum. Legislation in respective of other targets of Goal 5 will then be meaningful. Implementation of these is feasible in the next 15 years. They would have revolutionary effect on the status of women and the attainment of the SDGs by Africa. A wise person said that if you want to know the condition of a country, look at the status of its women citizens. Gender equality is the barometer of the SDGs and it is attainable.
Conflict of Interest: None

\section{References}

1. http://www.un.org/sustainabledevelopment/develop ment-agenda/.

2. http://www.un.org/sustainabledevelopment/sustaina ble-development-goals/.

3. http://www.un.org/en/africa/osaa/peace/sdgs.shtml.

4. http://www.un.org/africarenewal/magazine/decemb er-2015/agenda-2063-harmony-sdgs.

5. Susan Nicolai et al (2016), Projecting Progress: the SDGs in Sub-Saharan Africa, Overseas Development Office, London.

6. http://www.unwomen.org/en/news/in-focus/womenand-the-sdgs/sdg-5-gender-eq. 